\title{
EKSPERIMEN GETARAN PADA ROBOT MANIPULATOR YANG BERGERAK TRANSLASI
}

\author{
Dermawan Suddin, Abdul Kadir Muhammad ${ }^{1)}$
}

\begin{abstract}
Abstrak: Robot manipulator banyak digunakan dalam aplikasi di industri manufaktur dan diharapkan mampu mencapai kinerja yang baik, mampu meningkatkan akurasi posisi, operasional yang aman, komsumsi energi yang rendah, serta memiliki bobot yang lebih ringan. Penelitian ini dikhususkan pada pembuatan sebuah robot manipulator sebagai prototype dengan memfokuskan pada kondisi gerakan translasi. Dalam penelitian ini juga akan dibuat sebuah alat ukur getaran yang digunakan untuk mungukur frekwensi dan amplitudo percepatan dengan menggunakan accelarometer ADXL 335. Data yang diperoleh akan di tampilkan dalam bentuk grafik FFT frekuensi dan FFT amplitudo percepatan pada software spider. Dengan menggunakan metode Fast Fourier Transform, dapat diketahui frekwensi getaran yang terjadi pada manipulator. Pada penelitian ini menggunakan manipulator dari bahan aluminium dengan panjang $30 \mathrm{~cm}$ dan tebal $0,3 \mathrm{~cm}$. Dari hasil pengukuran yang telah dilakukan maka diperoleh frekwensi analisis sebesar 6,71 Hz. Sedangkan frekwensi eksperimen diperoleh sebesar 6,41 Hz. Pada penelitian ini nantinya akan menggunakan sebuah program komputasi yang akan mengontrol pergerakan robot. Metode yang digunakan adalah metode Desain dan Analisis Eksperimental.
\end{abstract}

Kata kunci: Gerak translasi, manipulator fleksibel, frekwensi.

\section{PENDAHULUAN}

Robot manipulator dengan satu link memiliki lengan yang dapat dianggap sebagai sebuah balok. Teori yang terkenal dalam menurunkan model matematika untuk sebuah balok adalah Teori Euler-Bernoulli. Kemudian Rayleigh memperbaiki model Euler-Bernoulli ini dengan menambahkan efek inersia rotasional yang disebabkan oleh gerak rotasi dari cross-sectionselama terjadi getaran melentur. Ditinjau dari gerakannya, robot manipulatormenimbulkan masalah baru karena harus mempertimbangkan deformasi yang terjadi akibat gerak translasi dan rotasi. Getaran yang ditimbulkan karena fleksibilitasnya juga menjadi persoalan yang sangat penting. Getaran ini harus mampu dikontrol agar sistem kerja dari robot manipulatortetap dalam kondisi ideal. Agar bisa dilakukan pengontrolan maka perlu mengetahui frekwensi dan amplitude dari sebuah sistem.

Gerak merupakan perpindahan posisi atau kedudukan suatu titik atau benda terhadap titik acuan tertentu. Berdasarkan bentuk lintasannya gerak dapat dibedakan menjadi dua jenis yaitu gerak translasidan gerak rotasi.Gerak translasi dapat didefinisikan sebagai gerak pergeseran suatu benda dengan bentuk dan lintasan yang sama di setiap titiknya. Jadi sebuah benda dapat dikatakan melakukan gerak translasi (pergeseran) apabila setiap titik pada benda itu menempuh lintasan yang bentuk dan panjangnya sama.

Manipulator fleksibel yang mengalami gerak translasi bisa dilihat pada gambar di bawah ini:

\footnotetext{
${ }^{1}$ Staf Pengajar Jurusan Teknik Mesin Politeknik Negeri Ujung Pandang
} 


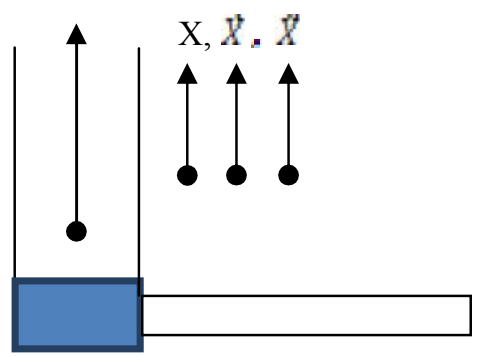

Dimana:

Gambar 1. Arah gerak translasi pada manipulator

$X=$ perpindahan

$\dot{X}=$ Kecepatan

$\ddot{X}=$ percepatan

Sedangkan gerak rotasi dapat didefinisikan sebagai gerak suatu benda dengan bentuk dan lintasan membentuk sudut gerak (Rotatinal angel). Gerak rotasi pada sistem manipulator fleksibel dapat dilihat pada gambar 2 berikut:

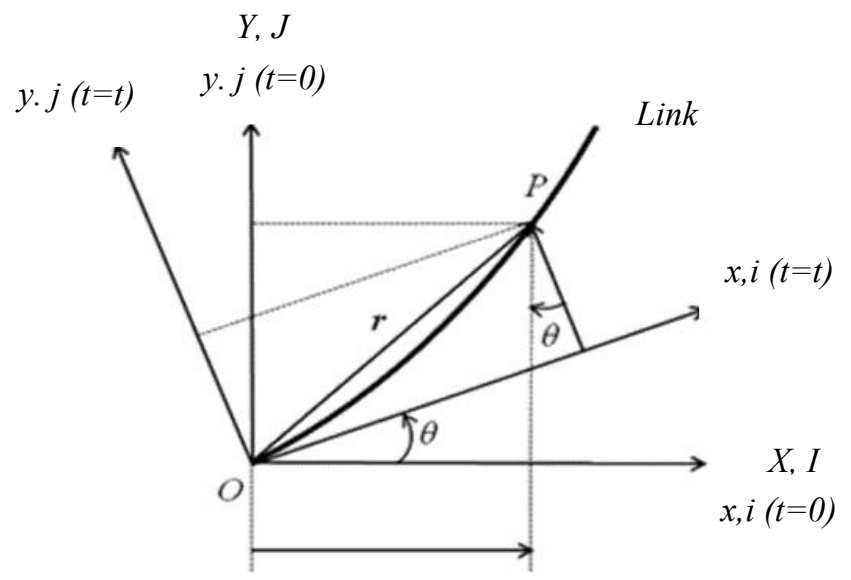

Gambar 2. Arah gerak rotasi pada manipulator

Penyebab suatu benda mengalami gerak translasi karena adanya gaya yang bekerja pada benda tersebut. Sedangkan, penyebab suatu benda mengalami gerak rotasi karena adanya momen gaya (torsi) yang bekerja pada benda tersebut.Berdasarkan hal tersebut di atas, maka peneliti akan merencanakan sebuah penelitian dengan judul "Rancang Bangun Robot Manipulator yang bergerak secara Translasi dan Rotasi".

Tujuan dari penelitian ini adalah untuk membuat sebuah robot manipulator yang melakukan gerak translasi dan rotasi dengan menggunakan program komputer dalam pengoperasiannya dengan mengharapkan dapat mengetahui frekwensi getaran yang ditimbulkan akibat kedua gerakan translasi dan rotasi tersebut. Sebagai langkah awal maka peneliti akan memfokuskan pengambilan data terlebih dahulu hanya pada gerakan translasi. Untuk penelitian selanjutnya akan menganalisis penggabungan kedua gerakan tersebut.

Eksperimen getaran bebas untuk mengetahui karakteristik sistem dengan mengukur simpangan pada getaran bebas dan akan menghasilkan sebuah grafik simpangan. Selanjutnya, hasil dari simpangan tersebut ditransfer menjadi 
157 Dermawan Suddin, Abdul Kadir Muhammad, Eksperimen Getaran pada Robot Manipulator yang Bergerak Translasi

frekwensi dengan metode Fast Fourier Transform (FFT).Eksperimen getaran manipulator yang bergerak translasi untuk mengukur simpangan sistem pada saat bergerak dan akan menghasilkan sebuah grafik simpangan. Selanjutnya, hasil dari simpangan tersebut ditransfer menjadi frekwensi dengan metode Fast Fourier Transform (FFT).

Model dari singel Link Manipulator seperti pada gambar di bawah ini;

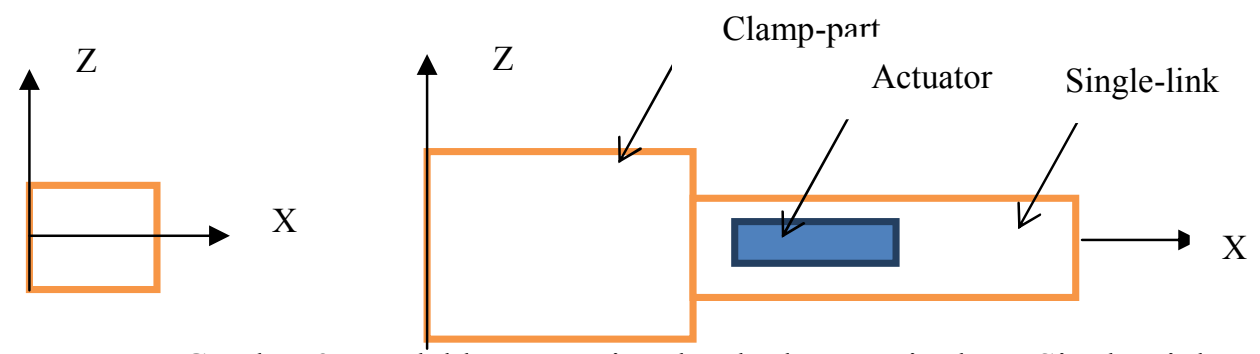

Gambar 3. Model komputasional terhadap Manipulator Single Link

Pada penelitian ini akan menganalisis getaran yang terjadi pada sistem singel-link manipulator.

Sistem yang digunakan dalam penelitian ini terdiri dari balok aluminium sebagai link yang fleksibel, klem, motor servo untuk memutar link. FFT (Fast Fourier Transform) pengolahan analisis yang dikembangkan untuk menghitung sifat dinamis dari manipulator link. Sistem dan skema kontrol yang diusulkan akan diperoleh melalui eksperimen. Program computer yang digunakan pada penelitian ini yaitu spyder.

\section{METODE PENELITIAN}

Pada penelitian ini, kami akan menggunakan Metode Desain dan Analisis Eksperimental dengan tujuan merancang suatu robot manipulator yang bergerak secara translasi dan rotasi serta menganilisis getaran yang terjadi akibat gerak translasi dan rotasi. Secara garis besar, akan digambarkan dalam sebuah diagram alir penelitian.

\section{A. Model Rancangan Robot Manipulator}

Model rancangan robot manipulator yang mengalami gerak translasi dan rotasi:

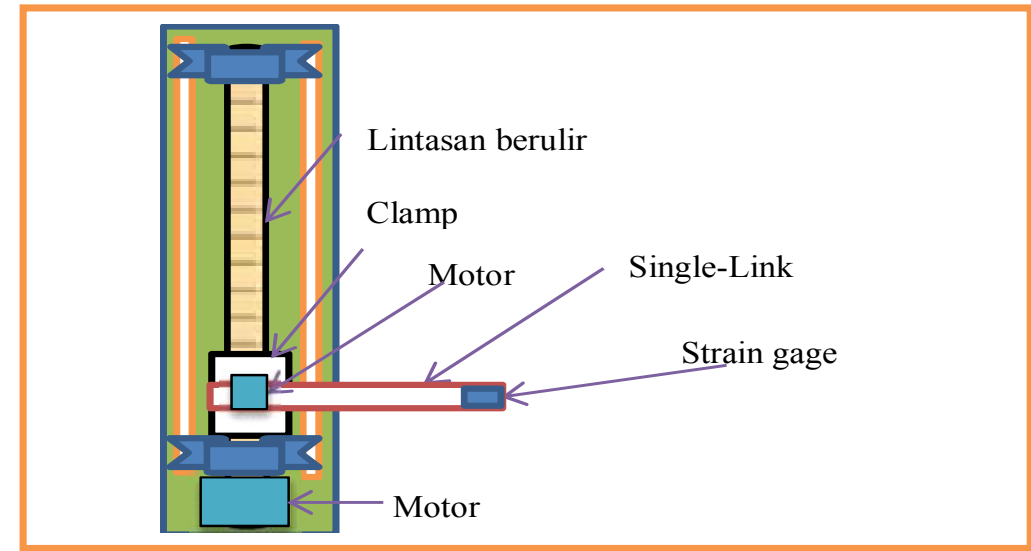

Gambar 4. Model rancangan 2DSingle-link manipulator gerak translasi dan rotasi 


\section{B. Sensor Getaran}

Sensor getaran adalah suatu alat yang berfungsi untuk mendeteksi adanya getaran dan akan diubah ke dalam sinyal listrik. Sensor getaran merupakan salah satu sensor yang dapat mengukur getaran suatu benda yang nantinya dimana data tersebut akan diproses untuk kepentingan percobaan ataupun digunakan untuk mengantisipasi sebuah kemungkinan adanya bahaya. Salah satu jenis sensor getaran yang saat ini sering digunakan adalah accelerometeryang berfungsi untuk mengukur percepatan, mendeteksi dan mengukur getaran (vibrasi). Berikut ini merupakan contoh sensor accelerometer dengan tipe ADXL335 (Adafruit. 2016).

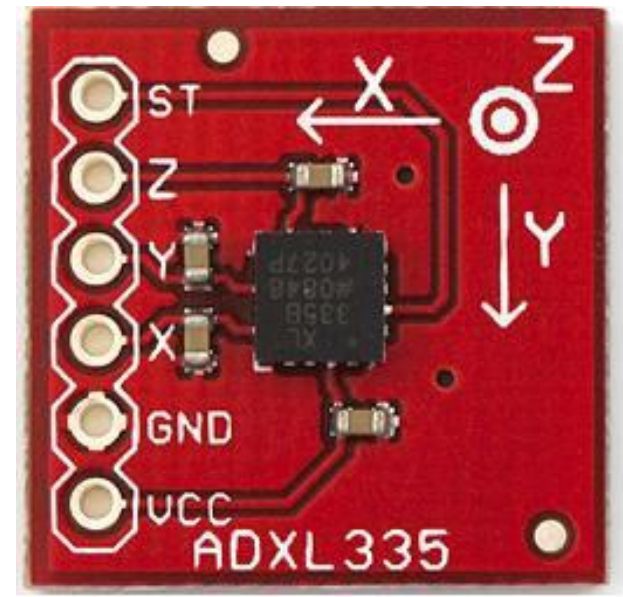

Gambar 5. Sensor Accelerometer ADXL335

Pada pengukuran getaran ini, digunakan sensor Accelarometer ADXL335 yang berfungsi untuk mengukur getaran (vibrasi) dengan tiga sumbu yakni sumbu X, Y dan Z. Bandwidth kerja accelerometer dapat diatur dengan menggunakan kapasitor $\mathrm{Cx}, \mathrm{Cy}$, dan $\mathrm{Cz}$ yang dipasang secara seri dengan pin Xout, Yout, dan Zout. Arduino Nano digunakan sebagai sistem akuisisi data, ini berisi USB to serial converter dan saluran ADC dan komputer adalah penganalisis FFT (Fast Fourier Transform), menggunakan library Python dan Numy, Scipy dan Matplotli. Arduino Nano mendengarkan perintah masuk dari komputer, yang memberitahukannya untuk memulai atau menghentikan pengiriman bacaan ADC. ADC membaca saluran getaran akselerometer pada frekuensi sampling tertentu $(5000 \mathrm{~Hz})$, yang dikontrol oleh salah satu timer mikrokontroler. Pembacaan ini dikirim pada port serial dengan kecepatan 0,5 Mbps.

\section{Tahapan penelitian}

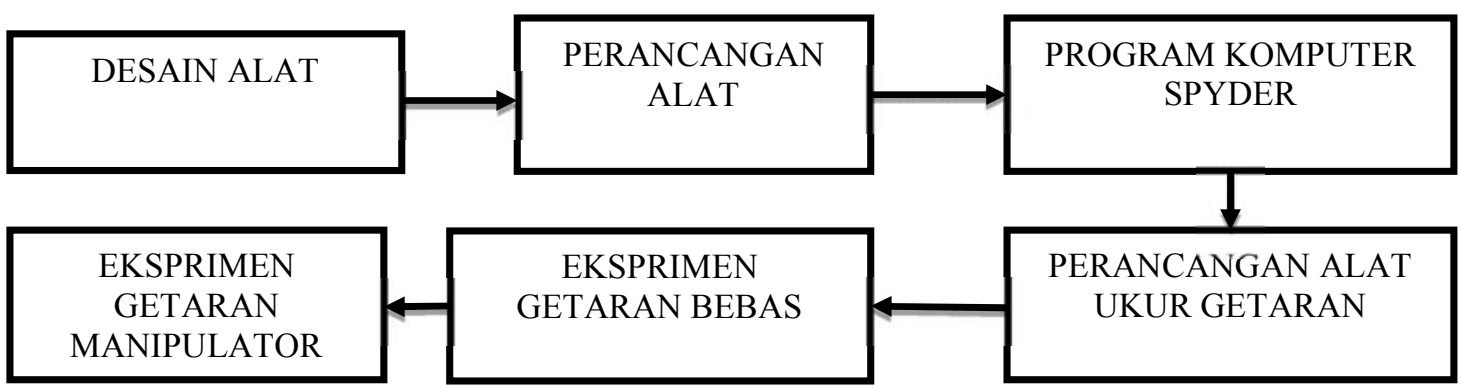

Gambar 6. Alur Penelitian 
159 Dermawan Suddin, Abdul Kadir Muhammad, Eksperimen Getaran pada Robot Manipulator yang Bergerak Translasi

Adapun tahapan penelitian dapat dirincikan sebagai berikut:

1. Desain alat

a. Membuat desain gambar dari robot manipulator fleksibel.

b. Membuat mekanik dari sistem robot, kemudian membuat rangkaian bersama motor servo untuk gerak rotasi dan motor DC untuk gerak translasi melalui poros berulir.

c. Merangkai driver untuk kedua motor tersebut.

2. Membuat Program

a. Buat coding/program untuk kedua motor tersebut dengan menggunakan mikrokontroller.

b. Uji coba program, jika terdapat masalah maka dilakukan perbaikan, kemudian diuji coba lagi sampai mendapatkan hasil yang diinginkan.

3. Pemasangan alat ukur getaran

a. Pasang strain gage pada manipulator.

b. Pasang rangkaian alat ukur getaran.

4. Eksperimen getaran bebas untuk mengetahui karakteristik sistem.

a. Melakukan eksperimen untuk mengukur simpangan pada getaran bebas.

b. Melakukan plot simpangan (akan diperoleh grafik simpangan).

c. Transfer hasil simpangan menjadi frekuensi dengan metode FFT/fast fourier transform (akan diperoleh grafik frekuensi)

d. Analsis grafik tentang simpangan, amplitudo, frekuensi dan priode system.

5. Eksperimen getaran manipulator yg bergerak translasi dan rotasi

a. Gerakkan robot secara translasi.

b. Ukur simpangan sistem pada saat sedang bergerak

c. Transfer hasil simpangan menjadi frekuensi dgn metode FFT/fast fourier transform

d. Analsis grafik tentang simpangan, amplitudo, frekuensi dan priode sistem Gambar 7 menampilkan skema aliran proses dalam pengambilan data getaran dengan menampilkan hasil pada layar komputer.

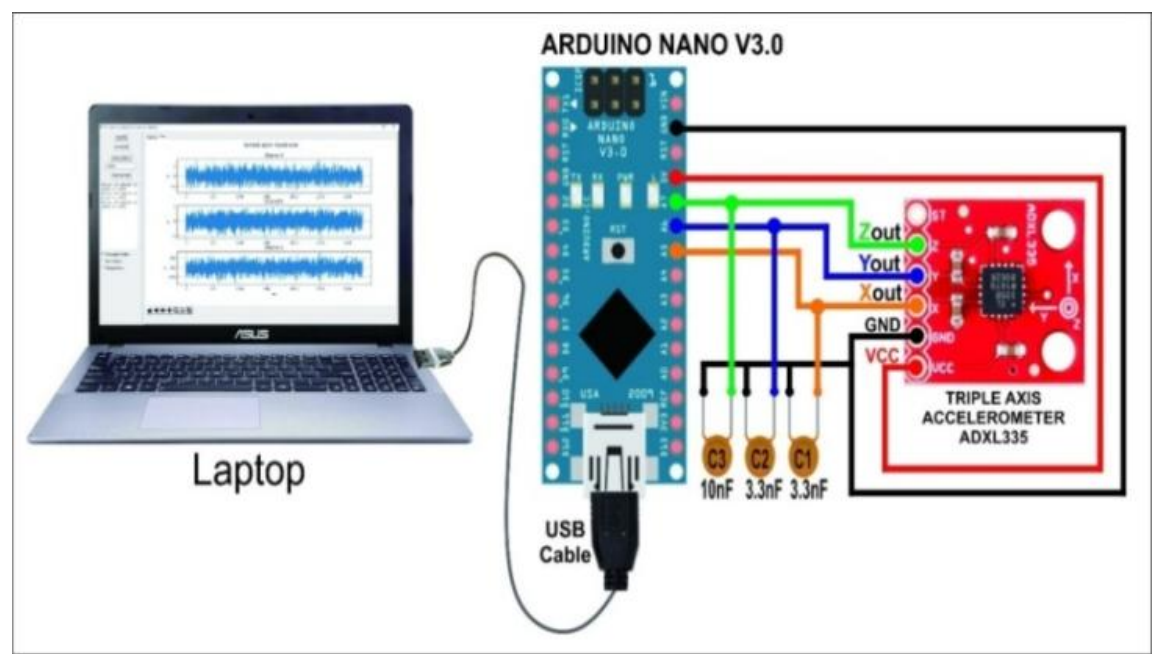

Gambar 7. Diagram alat ukur getaran 


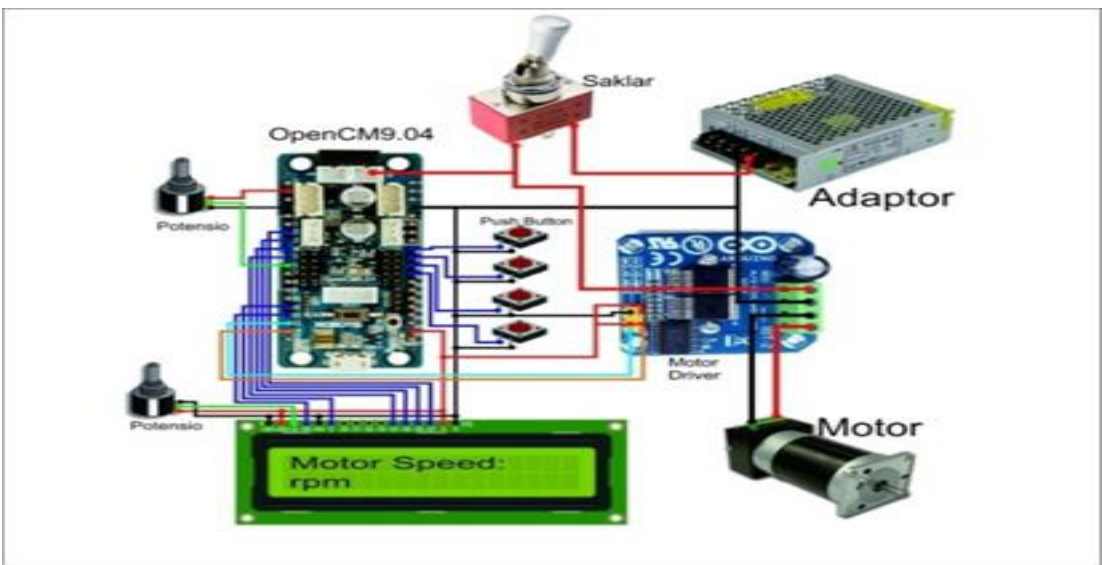

Gambar 8.Skema Sistem Elektronik single-link manipulator fleksibel

Pada gambar 8. menampilkan skema sistem elektronik single-link manipulator fleksibel pada sistem yang akan dibuat.Pada skema ini terdapat adaptor yang berfungsi sebagai catu daya untuk mikrokontoler dan motor. Motor pada manipulator akan bergerak berdasarkan perintah yang diinputkan dari push button. Pada sistem terdapat sebuah LCD 16x2 cm Untuk menampilkan kecepatan motor, arah pergerakan motor, dan motor on/off. Potensiometer dipasang untuk mengatur kecepatan motor.

\section{2Model Eksperimen}

Gambar 9a. menunjukkan model eksperimen getaran bebas pada single link manipulator fleksibel. Link dijepit dengan ragum kemudian diberikan gangguan padanya. Link tersebut mengalami getaran bebas dan frekwensi dan amplitude akan ditunjukkan pada layar computer. Pada gambar 9b. menunjukkan model eksperimen getaran pada single link manipulator fleksibel. Motor menggerakkan manipulator dengan memutar poros berulir. Manipulator yang pada ujungnya dipasangkan alat ukur getaran akan menampilkan frekwensi yang ditunjukkan pada layar monitor pada komputer.

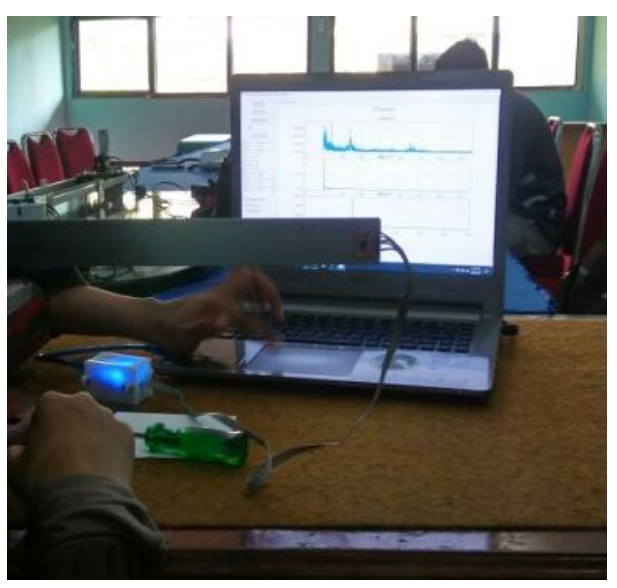

Gambar 9a. Eksperimen getaran bebas

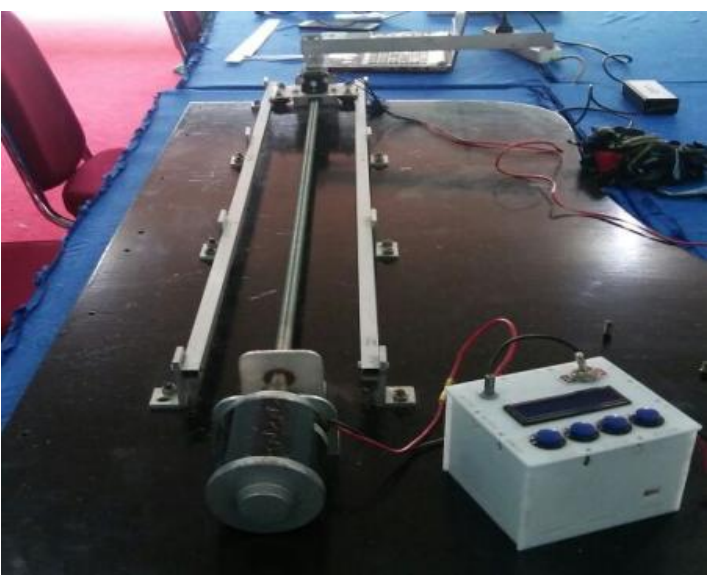

Gambar9b. Eksperimen getaran pada single link 
161 Dermawan Suddin, Abdul Kadir Muhammad, Eksperimen Getaran pada Robot Manipulator yang Bergerak Translasi

\section{HASIL DAN PEMBAHASAN}

\section{A. Hasil rancangan}

Setelah melalui sebuah desain dan perancangan, robot manipulator telah dihasilkan dalam bentuk prototype sederhana seperti pada gambar 10. Robot manipulator dengan sebuah link yang dipasang yang digerakkan oleh motor servo. Motor DC dipasang untuk pergerakan translasi dari manipulator fleksibel melalui sebuah poros berulir. Kontrol pergerakan dipasangkan untuk mengatur kecepatan, arah gerakan, serta On/Off dari robot. Motor servo yang berfungsi sebagai penggerak manipulator dalam arah rotasi. Pada ujung link fleksibel dipasangkan sebuah alat ukur getaran yang disambungkan dengan sebuah komputer. Pada saat pengujian dengan menggunakan software spyder maka akan menghasilkan luaran berupa frekwensi getaran dan ditampilkan dalam sebuah grafik.

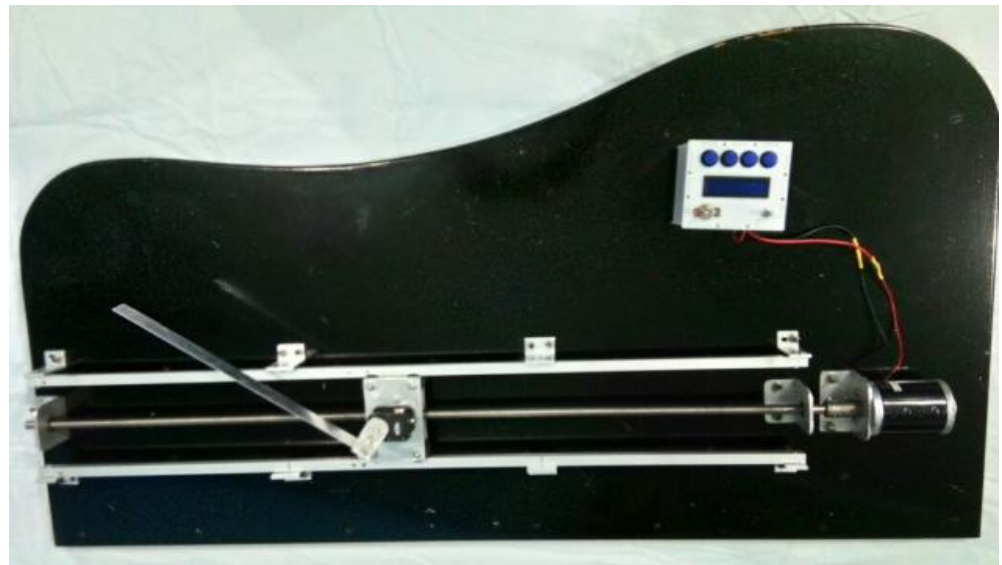

Gambar 10. Robot Manipulator Fleksibel

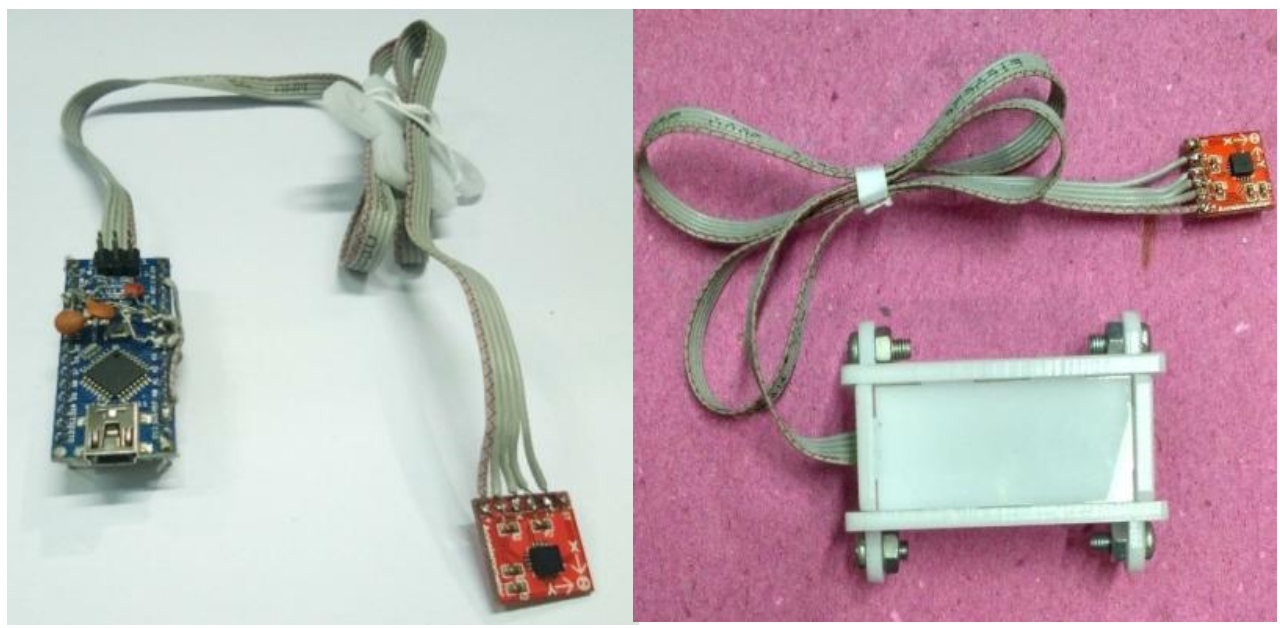

Gambar 11. Alat ukur getaran

\section{B. Analisis Getaran}

Untuk menentukan keakuratan nilai yang terukur pada alat ukur getaran dilakukan dengan perhitungan manual untuk mendapatkan data frekuensi suatu kantilever beam dengan satu derajat kebebasan. Berikut adalah perhitungan secara manual untuk panjang kantilever beam $0.30 \mathrm{~m}$. 
Diketahui:

Height $[\mathrm{h}]$

Bold [ b ]

Panjang Beam [ L ]

Massa Beam [ $\mathrm{m}$ ]

Kondisi Kantilever Beam $\left[\mathrm{X}_{1}\right]=3.516$ (Berunjuk pada Gambar 2.3)

Elastisitas Beam ( E )

Inersia Beam ( I)

$$
\begin{aligned}
& =0.001 \mathrm{~m} \\
& =0.03 \mathrm{~m} \\
& =0.30 \mathrm{~m} \\
& =0.01017 \mathrm{~kg} \\
& 6 \text { (Berunjuk pada Gam } \\
& =70 \times 10^{9}\left(\mathrm{~N} / \mathrm{m}^{2}\right) \\
& =2.083 \times 10^{-12} \mathrm{~m}^{4}
\end{aligned}
$$

Persamaan yang digunakan untuk mencari nilai momen inersia pada kentilever beam adalah sebagai berikut:

$$
\begin{aligned}
& I=\frac{1}{12} b h^{3} \\
& I=\frac{0.03 \mathrm{~m} \times 0.001^{3} \mathrm{~m}}{12} \\
& I=2.5 \times 10^{-12} \mathrm{~m}^{4}
\end{aligned}
$$

Dengan mengetahui moment inersia pada kentilever Beam, maka kecepatan sudutnya dapat dicari dengan menggunakan persamaan berikut:

$\omega_{n}=\frac{X_{1}^{2}}{L} \sqrt{\frac{E I}{m L}}$

$\omega_{n}=\frac{3.516}{0.30 \mathrm{~m}} \sqrt{\frac{70 \times 10^{9} \mathrm{~N} / \mathrm{m}^{2} \times 2.5 \times 10^{-12} \mathrm{~m}^{4}}{0.01017 \mathrm{~kg} \times 0.30 \mathrm{~m}}}$

$\omega_{m}=57.29 \mathrm{rad} / \mathrm{s}$

Nilai $\omega_{n}$ digunakan untuk mencari frekuensi pada kantilever beam dengan menggunakan persamaan 2.3.

$f$ analisis $=\frac{1}{2 \pi} \omega_{n}$

$f$ analisis $=\frac{1}{2 \pi} 57.23 \mathrm{rad} / \mathrm{s}$

$f$ analisis $=9,11 \mathrm{~Hz}$

Hasil analisis di atas dapat kita lihat ada perbedaan nilai frekwensi antara data perhitungan manual ( $\mathrm{f}$ analisis $=9.11 \mathrm{~Hz}$ ) dan data hasil pengukuran getaran(frekuansi pengujian $=9.25 \mathrm{~Hz}$ pada tabel1) . Maka untuk mendapatkan nilai pembacaan yang akurat pada alat ukur getaran dilakukan linierisasi data sebagai berikut:

$$
\begin{aligned}
& \alpha=\frac{\Delta y \mathrm{f} \text { analisis }}{\Delta \mathrm{xfeksperimen}} \\
& =\frac{(41,8935-13,1398) \mathrm{Hz}}{(27,164-9,461) \mathrm{Hz}} \\
& =1,45
\end{aligned}
$$

Dengan mendapatkan nilai dari $\boldsymbol{\alpha}$ maka $\mathrm{f}_{\text {terukur }}$ dapat dihitung sebagai berikut:

$f$ terukur $=\alpha x f$ pengujian

$f$ terukur $=1.45 \times 5.49 \mathrm{~Hz}$

$f$ terukur $=7,96 \mathrm{~Hz}$

Nilai Frekuensi terukur $(\mathrm{Hz})$ yang didapatkan di atas adalah nilai frekuensi $(\mathrm{Hz})$ yang sebenarnya yang digunakan pada alat ukur getaran setelah dilakukan 
163 Dermawan Suddin, Abdul Kadir Muhammad, Eksperimen Getaran pada Robot Manipulator yang Bergerak Translasi

perbaikan pada kode program dengan menambahkan perkalian alfa pada frekuensi pengujian $(\mathrm{Hz})$.

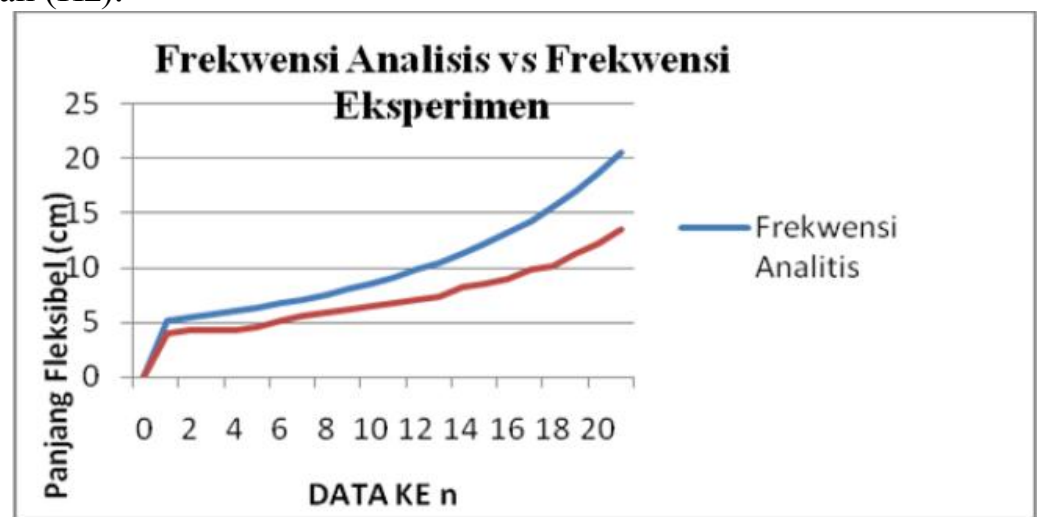

Gambar 12. Grafik Frekwensi Analisis vs Frekwensi Eksperimen

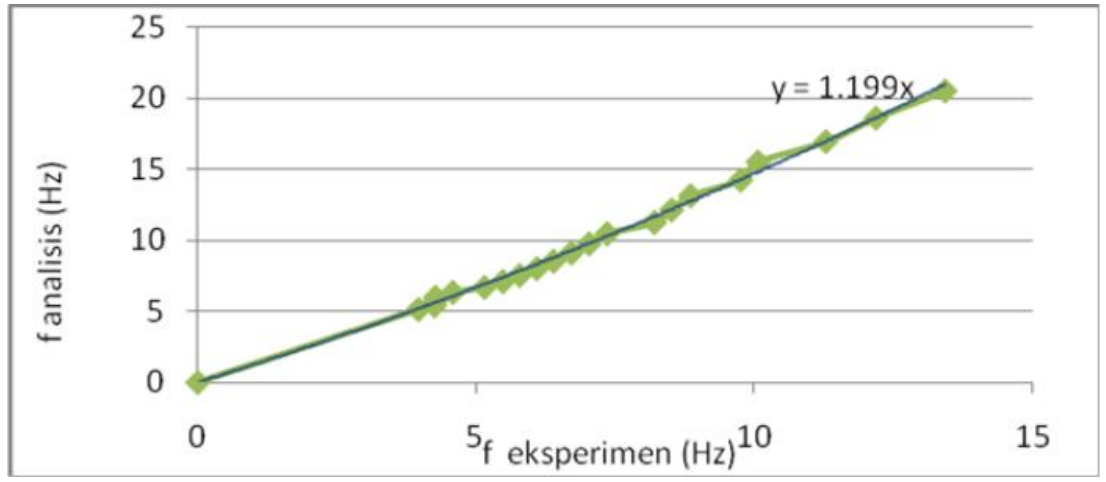

Gambar 13. Grafik linearisasi data

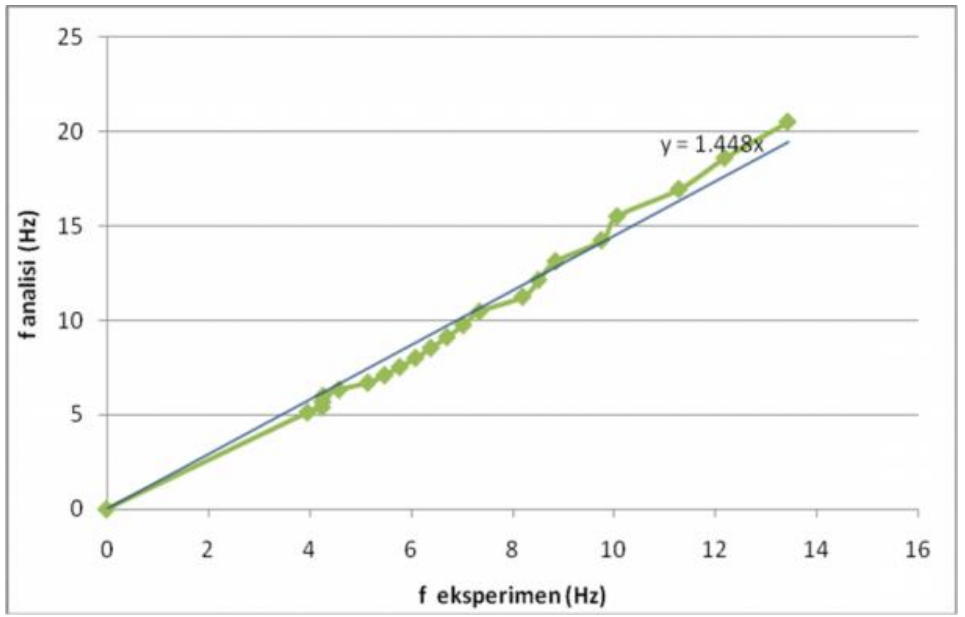

Gambar 14. Grafik penentuan nilai $\alpha$

Dari hasil pengambilan data Grafik di atas menunjukkan bahwa $f_{\text {analisis }}$ memiliki nilai yanghampir sama dengan nilai $f_{\text {eksperimen. }}$ Hal ini dapat dilihat pada grafik yang cenderung linear. Hal ini menunjukkan bahwa alat yang di desain telah memenuhi tujuan awal dari penelitian ini dan bisa digunakan sebagai alat praktikum di laboratorium dan dapat digunakan untuk penelitian selanjutnya. 
Hasil Eksperimendapat dilihat pada gambar 12. dengan menggunakan robot manipulator: $\mathrm{f} 1=6,41 \mathrm{~Hz}, \mathrm{f} 2=50,05 \mathrm{~Hz}, \mathrm{f} 3=150,16 \mathrm{~Hz}$. Jika dibandingkan dengan hasil analisis dan eksperimen tanpa menggunakan gerakan robot, pada kondisi dan posisi di $\mathrm{L}=30 \mathrm{~cm}$, dapat ditunjukkan bahwa frekwensinya hampir sama pada saat robot bergerak secara translasi. Hal ini disebabkan karena hasil dari desain dan perancangan robot manipulator dapat mencapai kondisi ideal yang diinginkan. Dengan menggunakan program Spyder

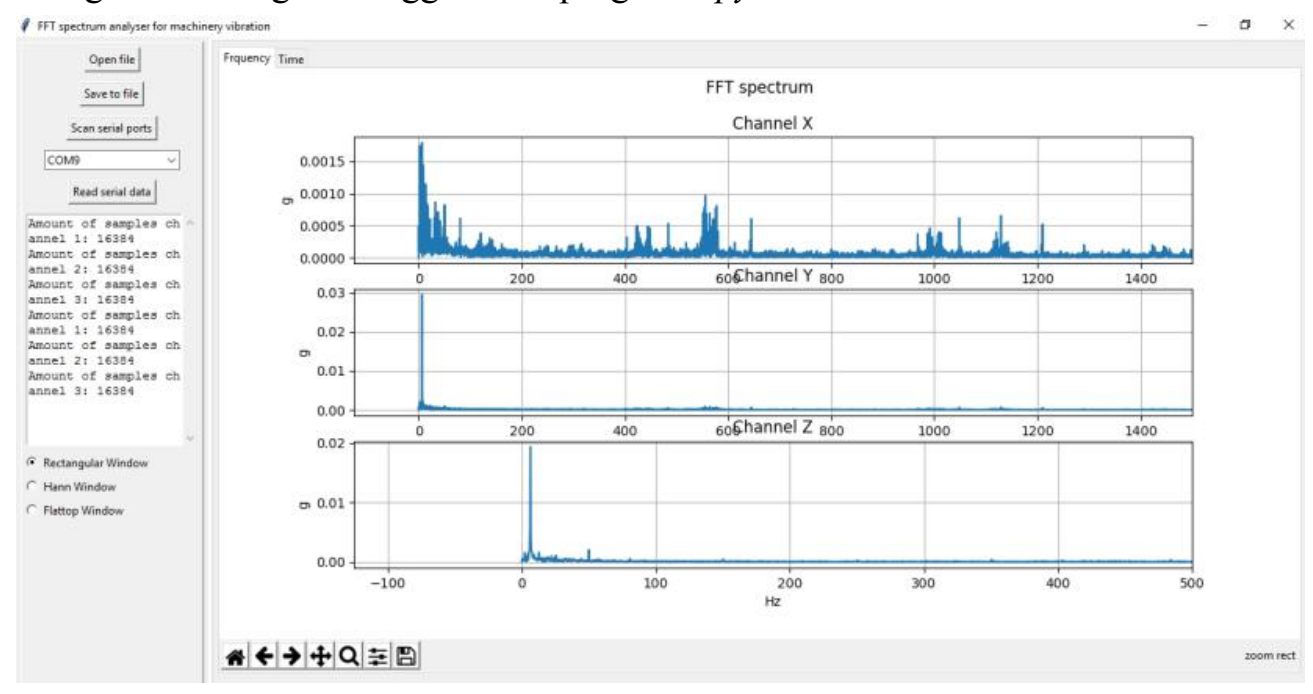

Gambar 15. Tampilan alat ukur untuk pembacaan grafik FFT frekuensi

\section{KESIMPULAN}

a. Dari hasil analisis dan eksperimen menunjukkan bahwa frekwensi yang dimiliki hampir sama antara frekwensi analisis dan frekwensi eksperimen. Hal ini menunjukkan bahwa rancangan robot single-link manipulator fleksibel berhasil dengan baik.

b. Robot manipulator berhasil dibuat dengan penggabungan dua buah gerakan yaitu gerak translasi dan rotasi, walaupun eksperimen yang dilakukan masih pada gerakan translasi.

c. Semakin panjang link manipulator, maka frekwensi yang dihasilkan semakin besar.

\section{DAFTAR PUSTAKA}

A.K. Muhammad,2015,_Finite_Element_Analysis_for_Active force Control on Vibration of a Flexible Single link Manipulator, International Journal on Smart Material and Mechatronics, IJSMM Vol. 2 No. 2

A.K. Muhammad et al, 2014, "Computer Simulations and Experiments on Vibration Control of a Flexible Link Manipulator Using a Piezoelectric Actuator", Lecture Notes in Engineering and Computer Science: Proceeding of The International MultiConference of Engineers and Computer Scientists 2014, IMECS 2014, 12 - 14 March, 2014, Hong Kong, pp. $262-267$. 
165 Dermawan Suddin, Abdul Kadir Muhammad, Eksperimen Getaran pada Robot Manipulator yang Bergerak Translasi

Adafruit. 2016. ADXL345 Digital Accelerometer. Cdn-shop, (Online), (https://cdnshop.adafruit.com/1200x900/1231-00.jpg), diakses 8 Februari 2017.

D. Suddin dan B. Nasrullah, 2017, "Rancang Bangun Robot Manipulator yang bergerak secara Translasi dan Rotasi"Prosiding Seminar Hasil Penelitian (SNP2M) 2017 (pp.152-157).

S. Mahto, A. K. Gogoi, and U. S. Dixit, 2016, "A Comparative Study of Improved Dynamics of Single Link Flexible Revolute-Jointed Robotic Manipulator," Procedia Eng., vol. 144, pp. 425-434.

H. N. Rahimi and M. Nazemizadeh, 2013 ,"Dynamic analysis and intelligent control techniques for flexible manipulators: a review," Adv. Robot., vol. 28 , no. 2 , pp. 63-76,

X. Yang and Z. Zhong, 2013, "Dynamics and Terminal Sliding Mode Control of Two-Link Flexible Manipulators with Noncollocated Feedback," IFAC Proc. Vol., vol. 46, no. 20, pp. 218-223.

Saeeb B. Niku, 2010, "Introduction to Robotics", John Wiley \& Sons, Second Edition, California.

M. Lalanne et al, 1983, Mechanical Vibration for Engineers,John Wiley \& Sons Ltd,. 